\title{
L1 Prosodic Interference: the CaSe of Slovene Students of Japanese
}

\author{
Nina GOLOB \\ University of Ljubljana, Slovenia \\ nina.golob@ff.uni-lj.si
}

\begin{abstract}
A bidirectional perception experiment was conducted on Japanese and Slovene subjects to evaluate the result of a full L1 prosodic interference in recognizing (lexical) accent place in declaratives and interrogatives. Perceptual hypercorrection into L1 prosody on the side of the listener was achieved by making the subjects think they were listening to their own language, and results show clear tendencies for errors, which in general agree with predictions. However, mapping from phonetic to phonological representations was found to be asymmetric, suggesting that subjects of the two languages rely on different phonetic cues, as well as that distinctive function of certain phonetic cues, such as duration, has different effects on perception of segmental structure.
\end{abstract}

Keywords: perception; lexical accent; L1 interference; Japanese; Slovene

\section{Povzetek}

Raziskava razkriva rezultate obojestranskega testa slušnega zaznavanja, ki ga je avtorica izvedla na slovenskih in japonskih slušateljih z namenom, da bi ocenila vpliv maternega jezika na prepoznavanje besednega naglasa $v$ besedah povednega in vprašalnega naklona. Percepcijska hiperkorekcija v prozodijo maternega jezika je bila dosežena tako, da so slušatelji mislili, da poslušajo besede v svojem maternem jeziku. Rezultati kažejo jasne tendence napak, ki se v splošnem skladajo s predvidevanji. Vendar pa hkrati rezultati kažejo, da je bilo uvrščanje fonetičnih oblik v fonološke nesimetrično, zaradi česar lahko sklepamo, da se slušatelji obeh jezikov pri slušnem zaznavanju besednega naglasa zanašajo na različne fonetične lastnosti. Poleg tega lahko sklepamo tudi, da ima pomensko-razločevalna funkcija fonetičnih lastnosti, kot je na primer trajanje, različne vplive na percepcijo segmentne strukture.

Ključne besede: slušno zaznavanje; besedni naglas; vpliv maternega jezika; japonščina; slovenščina

\section{Introduction}

Second language (L2) learners tend to make mental associations or interlingual identifications between structures of the two languages (Weinreich, 1953; Odlin, 1989; Jarvis \& Pavlenko, 2008), and first language (L1) interference is especially high when

Acta Linguistica Asiatica, 6(2), 2016.

ISSN: 2232-3317, http://revije.ff.uni-lj.si/ala/

DOI: 10.4312/ala.6.1.69-76 
phonological differences between $\mathrm{L} 1$ and $\mathrm{L} 2$ are hidden behind the phonetic similarities (Eckman et al., 1989; Eckman, 2008).

In this paper, a bidirectional perceptual experiment was conducted to discuss how well a learner perceives L2 accent place under the supposition of a full L1 prosodic interference, or in other words, how well a native listener can recognize accent place from the learner's 'foreign accent' pronunciation.

Much has been done on phonetics and phonology of Japanese accentuation (e.g. Haraguchi, 1977; Shibatani, 1972; Sugito, 1972; Uwano, 2003; etc.), and some on Slovene accentuation (e.g. Bhaskararao \& Golob, 2006; Srebot-Rejec, 1988, 1997; Šuštaršič, 1995, 2004; Toporišič, 1965, 2000; etc.) respectively, however, very little is known on the prosodic interference of the two languages ${ }^{1}$. A comparative study on acoustics of accentuation (Golob, 2005; Golob, 2011 compared Japanese pitch accent and Slovene stress accent) pointed out a different interaction of accentual and intonational tier in the two languages, and proposed a possible L1 interference as shown in Figure 1 (Golob, 2005).

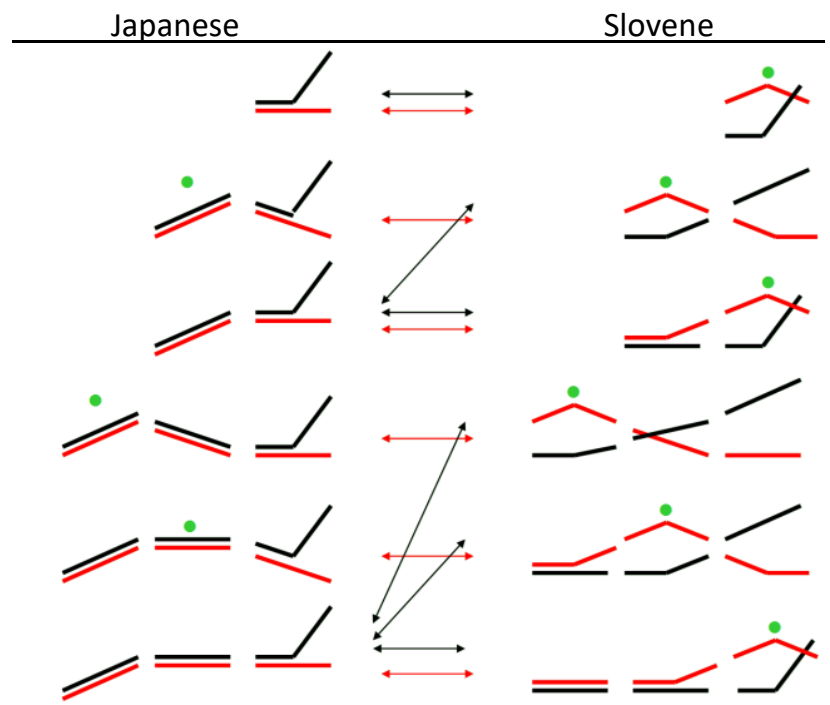

Figure 1: Hypothetical L1 interference between Japanese and Slovene based on pitch patterns. Declaratives are in red and interrogatives in black. Accent place is marked with a green dot.

Accent place in declaratives is expected to be perceived correctly since the similarities in pitch patterns stay within the so-called 'bilingual minimal pair'. This is not the case with interrogatives, where certain accent patterns in Japanese are expected to take more than one Slovene pattern while others show no matches.

\footnotetext{
${ }^{1}$ Prosodic influence was reported for Slovene speakers of Chinese, another language with tonal contrast (Petrovčič \& Lin, 2015).
} 
The present study aims to verify the above hypothesis and investigates on Japanese accent patterns that hypothetically show no matches. It further briefly examines the role of duration and intensity (which are ignored in the above hypothesis) in the misperception of an accent place.

\section{Perception experiment}

\subsection{Methodology}

Altogether 173 subjects, 106 Japanese and 67 Slovene native speakers, were asked to listen to their native language (reiterant speech, Larkey, 1983) and mark the accent place. The material, in total including 60 items, consisted of 2- and 3-syllabic words, half with Japanese and half with Slovene prosody, and chosen randomly from 10 Japanese and 10 Slovene native speakers. 'No accent place' answer option was given to Japanese subjects for the Japanese so-called heibangata accent pattern, cf. an accentless word, and was equated with the Slovene word accented on the final syllable.

Subjects scoring less than $50 \%$ in either declaratives or interrogatives of their native language were eliminated from further analysis (25 Japanese and 6 Slovene subjects).

\subsection{Results}

Figures 2a, 2b show results from 82 Japanese (top) and 61 Slovene subjects (bottom). Generally speaking, the difference between L1 and L2 perception was statistically significant for both groups of subjects $(p<0.001)$, error rate being higher for L2 perception. Japanese subjects show a very high score for both intonational surroundings in L1 (96.3\%, SD 9.0 and $94.7 \%$, SD 10.2) as well as for declaratives in L2 (96.4\%, SD 6.6), while L2 interrogatives, with only $41.6 \%$ in average (SD 6.9), show strong and clear error tendencies (see below). Slovene subjects also perceive accent places of L1 (89.0\%, SD 12.5 and $82.1 \%$, SD 14.1) better than those of L2 (76.7\%, SD 15.9 and $57.7 \%$, SD 17.9) but their error rate rises relatively evenly in both intonational surroundings, the tendency being typical for certain Japanese accent patterns (described in detail in 2.2.1). 

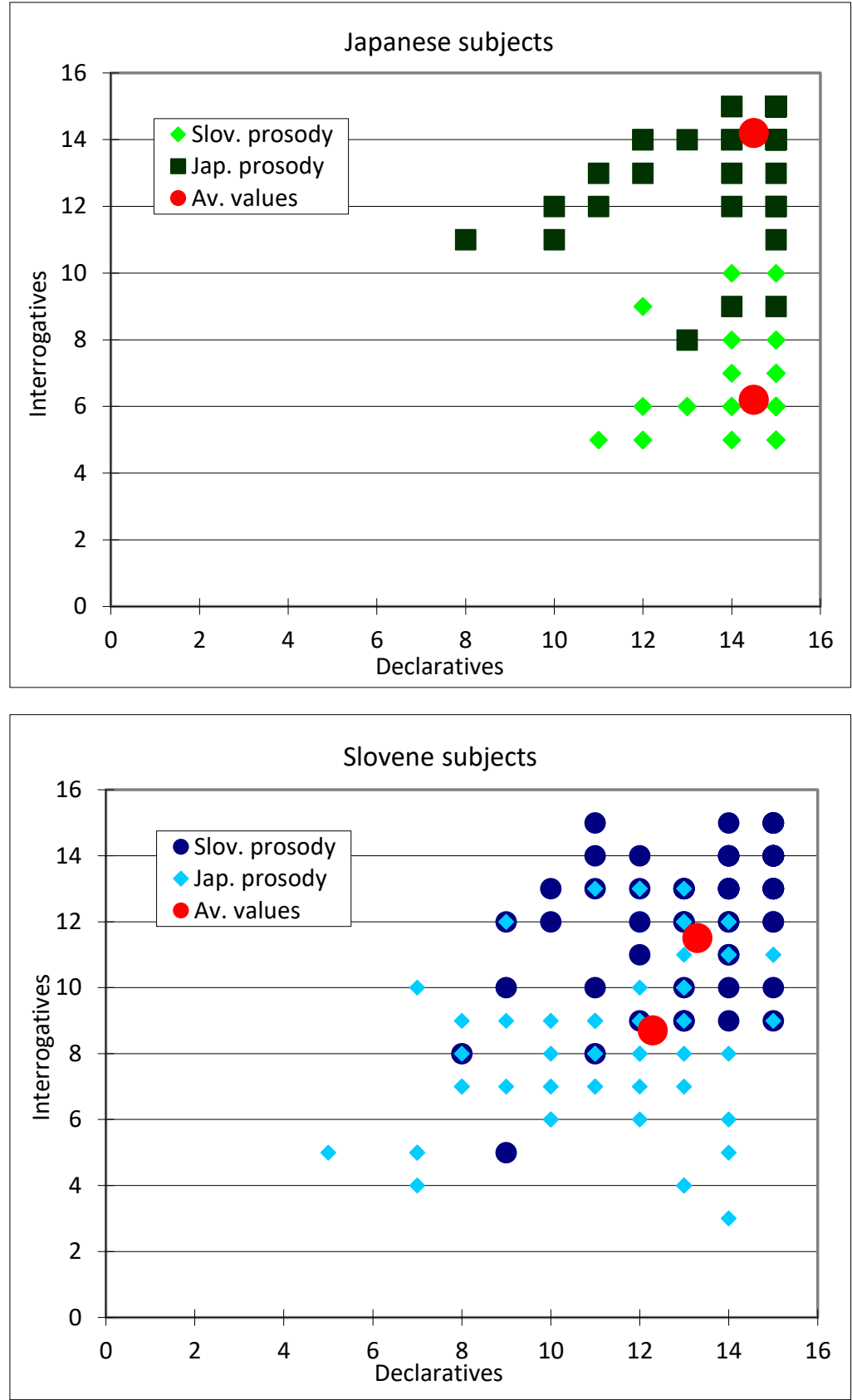

Figure 2a, 2b: Scattergrams showing correct answers in L1 and L2 perception by Japanese (top) and Slovene subjects (bottom). 


\subsubsection{Error analysis}

Error rates were observed based on accent patterns and error tendencies were further evaluated to conclude on general L1 interference.

Results for Japanese subjects show that error rates in declaratives are negligible (Figure $3 a)$, while in interrogatives (Figure 3b), there is a clear distinction between high and low error rates, depending on accent pattern. Validity is very low with words that are accented on a non-final syllable (average error rate is $92 \%$, SD 4.1), of which $89.4 \%$ (SD 3.9) of cases were judged to have accent on the final syllable.
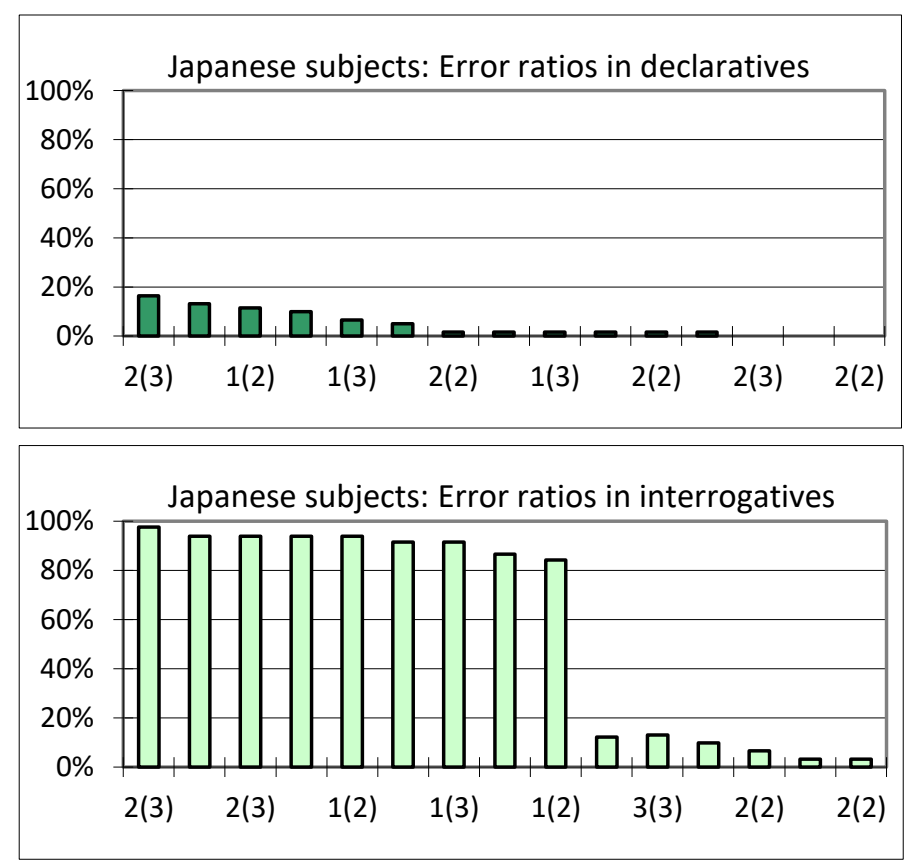

Figure 3a, 3b: Error rates for each word in declaratives (top) and interrogatives (bottom) by Japanese subjects. X-axis shows accent place and number of syllables in a word (in brackets).

Figures $4 \mathrm{a}$ and $4 \mathrm{~b}$ show that, irrespective of intonational surrounding, Slovene subjects tend to make most errors in cases of Japanese non-accented words (28.8\%, SD 16.5 and $50.2 \%$, SD 19.6), placing the accent onto the first syllable $(13.0 \%$, SD 7.0 and $20.3 \%$, SD 7.4$)$ or penultimate syllable $(11.7 \%$, SD 6.5 and 18.7\%, SD 12.4) in 3-syllabic words, and onto the first syllable in 2-syllabic words (10.1\%, SD 3.6 and 20.3\%, SD 5.5). Words accented on the first, penultimate, or first and penultimate syllable show slightly higher validity with the error ratios of $8.3 \%$, SD 3.2 and $16.0 \%$, SD 10.8, 16.7\%, SD 4.7 and $27.0 \%$, SD 7.5, 9.7\%, SD 6.0 and $24.3 \%$, SD 17.6, respectively. Their error tendencies seem to be random. 

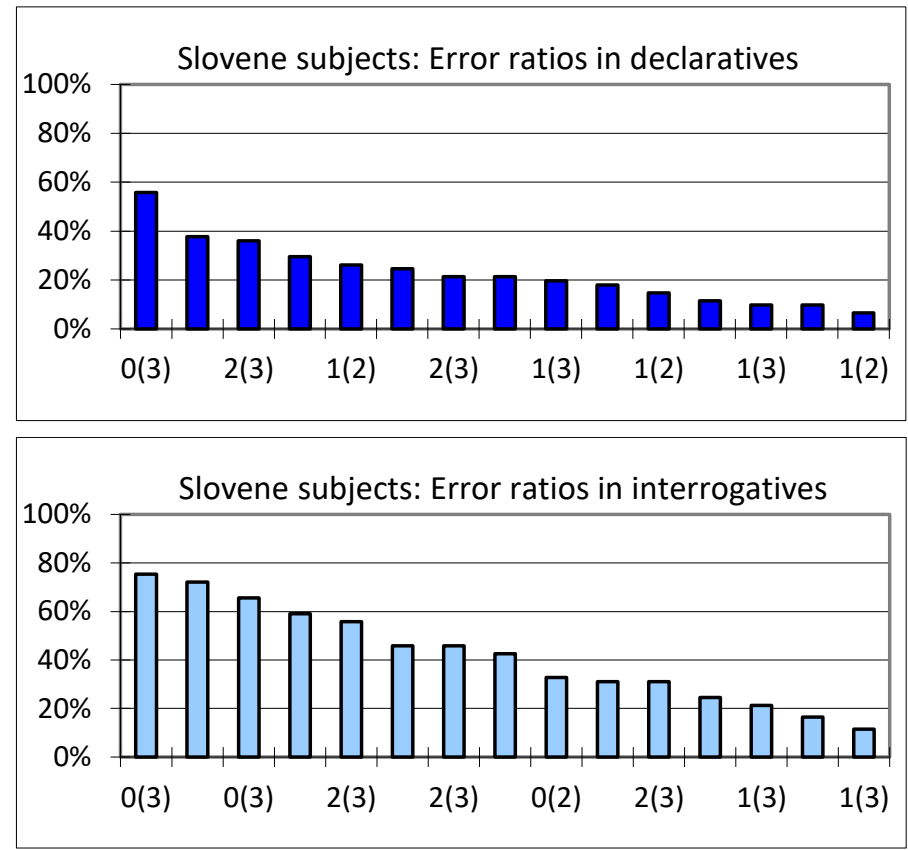

Figure 4a, 4b: Error rates for each word in declaratives (top) and interrogatives (bottom) by Slovene subjects. X-axis shows accent place and number of syllables in a word (in brackets).

\section{General discussion and conclusions}

A bidirectional study predicted symmetric mapping of phonetic information into L1 phonology. Predictions were confirmed for Japanese subjects, who extremely well perceived all but interrogatives with a non-final accent place, mistaking them for nonaccented words. Similar results were obtained by Ayusawa (reviewed in Ayusawa, 2003) for several other language groups, which additionally shows that Japanese native listeners rely on the pitch fall in perception of accent place (Sugito, 1972; Uwano, 2003). Despite the low error rate, some Japanese subjects pointed out the possible incorrect transcription on the answer sheet, claiming a missing moraic vowel on the accented syllable, which points at L1 prosodic characteristics interfering with segmental organization. On the other hand, Slovene subjects show a weak tendency to place accent on a non-final syllable, following a common accent patterning in Slovene (Toporišič, 2000 [1976]). In general, however, errors were observed to occur randomly, suggesting that pitch information alone is not sufficient to correctly perceive accent place. Duration was shown to be an important phonetic cue in Slovene (Bhaskararao \& Golob, 2006; Toporišič, 2000 [1976]), and further investigation is needed to show how much the lack of durational information (also those on intensity?) contributes to the misperception of accent place. 


\section{References}

Ayusawa, T. [鮎澤孝子] (2003). Gaikokujingakushuushano nihongo akusentointoneeshon shuutoku [外国人学習者の日本語アクセント・イントネーション習得]. Onseekenkyuu [音声研究], 7(2), 47-58.

Bhaskararao, P. \& Golob, N. (2006). What matters in Slovene accent? An acoustic comparion of stress and pitch accents. 1st Slovene International Phonetic Conference, Ljubljana.

Eckman, F., Moravcsik, E. \& Wirth, J. (1989). Implicational universals and interrogative structures in the interlanguage of ESL learners. Language Learning, 39(2), 173-205.

Eckman, F. (2008). Typological markedness and second language phonology. In J.G. HansenEdwards \& M.L. Zampini (Eds), Phonology and Second Language Acquisition (pp. 95-115). Amsterdam: John Benjamins Publishing Company.

Golob, N. (2005). Phonological approach to acoustic analysis of Japanese and Slovene prosody: accent and intonation. 11th International Conference of EAJS, Vienna.

Golob, N. (2011). Acoustic Prosodic Parameters in Japanese and Slovene: Accent and Intonation. Acta Linguistica Asiatica, 1(3), 25-44.

Haraguchi, S. (1977). The Tone Pattern of Japanese: An Autosegmental Theory of Tonology. Tokyo: Kaitakusha.

Larkey, L. S. (1983). Reiterant Speech: an acoustic and perceptual validation. Journal of the acoustical Society of America, 73(4), 1337-1345.

Odlin, T. (1989). Language transfer: Cross-linguistic influence in language learning. Cambridge: Cambridge University Press.

Petrovčič, M. \& Lin, M. (2015). Sodobna kitajščina 1. Ljubljana: Znanstvena založba Filozofske fakultete Univerze v Ljubljani.

Srebot Rejec, T. (1988). Word accent and vowel duration in standard Slovene: An acoustic and linguistic investigation. München: Verlag O. Sagner.

Srebot Rejec, T. (1997). Nekaj o stavčni intonaciji v knjižni slovenščini. Slavistična revija, 45(34), 429-455.

Šuštaršič, R. (1995). Naglas in poudarek v angleščini in slovenščini. Slavistična revija, 43(2), 157-182.

Šuštaršič, R. (2004). A contrastive analysis of the vowel qualities of English and Slovene. In E. González-Álvarez \& A. Rollings (Eds.), Studies of contrastive linguistics (pp. 601-608). Santiago de Compostela: Universidade de Santiago de Compostela.

Shibatani, M. (1972). The non-cyclic nature of Japanese accentuation. Language, 48(3), 584595.

Sugito, M. [杉藤美代子] (1972). 'Ososagari' koo: Dootai sokuteeni yoru nihongo akusentono kenkyuu [“㧈そ下り”考一動態測定による日本語アクセントの研究一]. In Tokugawa [徳川宗賢] (ed.). Ronshuu nihongo kenkyuu 2 Akusento [論集日本語研究 2 アクセント ]. Tokyo [東京]: Yuseido [有精堂].

Toporišič, J. (1965). Naglasni tipi slovenskega knjižnega jezika. Jezik in slovstvo, 10(2-3), 6-79. Toporišič, J. (2000 [1976]). Slovenska slovnica. Maribor: Obzorja. 
Uwano, Z. [上野善道] (2003). Akusentono taikeeto shikumi [アクセントの体系と仕組み]. Asakura nihongo kouza [朝倉日本語講座], 3. Tokyo [東京]: Asakurashoten [朝倉書店]. Weinreich, U. (1953). Languages in Contact: Findings and Problems. The Hague: Mouton.

\section{Acknowledgement}

My warm thanks are due to Prof. Hiroshi Nakagawa (Tokyo University of Foreign Studies) and Prof. Chikako Shigemori-Bučar (University of Ljubljana) who generously created the conditions for this experiment, and also to the subjects for their substantial contributions. 